satisfactory training for the examination, the B.O.A. has 'recognized' certain schools which have been inspected to ascertain that their equipment, staffing, and courses are satisfactory. These schools are mostly in the technical institutes in such towns as Manchester, Edinburgh, Glasgow, Bradford, Cardiff, etc. The largest classes are those at the Northampton Institute, London, where last session more than two hundred and thirty attended organized courses in addition to some sixty who took special courses or individual classes in optics. In Manchester in the same session twelve students were taking full-time courses and about forty were taking part-time courses for these examinations. In the other schools the numbers are of the order of a dozen students in the session. In addition to the optical training in these schools, arrangements are made in all cases for the students to attend some form of hospital course in order to enable them to recognize diseases of the eye, to ensure that patients so suffering shall be sent to obtain proper treatment.

Practical Optics. The fourth section of optical training, practical optics, is provided to a limited extent at all the 'recognized' schools, since it is included in the training of the sight-testing optician, who is expected to be able to grind, polish and edge a lens for a spectacle frame; but it is also arranged as an independent course both at the Northampton Institute and at the Manchester School of Technology. These special courses are planned for workers in optical factories; the students attend on three evenings a week for instruction in drawing, in optical calculations, and in actual lens- and prismgrinding and polishing. The industry so far does not seem to have appreciated the potential value of these classes, as there were less than ten students at either of the schools last session. In spite of the large use of machinery for the grinding and polishing of lenses and prisms, the very exact workmanship required in some cases (roof-prisms, for example, have to be worked to an angle which is correct within two seconds of arc) still necessitates hand finishing; for this and similar work, as well as to enable the men to use the machines in a more in. telligent and less 'rule-of-thumb' manner, such classes should surely be of very great value.

\title{
Inauguration of the German State Council for Research
}

\section{$\mathrm{I}_{\mathrm{s}}^{\mathrm{N}}$} $\mathrm{N}$ March of last year, the foundation of a new State Council for Research ("Reichsforschungsrat") was announced in Germany by the Minister of Education, Herr Rust. Within ten weeks the fourteen departments of the research organization were formed. In December last a handsomely printed quarto publication describing the Council and its purposes was issued with No. 23 for the year 1937 of the Official Gazette of the German Ministry of Learning, Training and National Education (Amstblatt der Reichs-Ministeriums für Wissenschaft, Erziehung und Volksbildung). It is entitled "A Celebration of German Learning" (Ein Ehrentag der deutschen Wissenschaft, 25 Mai 1937).

The publication sets out the system on which research is to be organized and the principles on which it is conducted in the Third Reich. It is illustrated with scenes of the inaugural ceremony and with large portraits of the Führer, the Minister of Education, the president of the new Council, Artillery-General Professor Dr. K. Becker, his acting deputy, the vicepresident, Dr. O. Wacker, and the directors of the various departments. Fourteen of these departments, all of a definitely technical character, have been established. The speeches of Herr Rust and of Prof. Becker are set out in large type and are followed by detailed records of the career of each director of a department.

In his address, Herr Rust directed attention to his ready action and indicated the need for the establishment of the Council. "The Council," he said, "is initiated at a moment when the German people is preparing, in a manner hitherto unprecedented and by an unexampled expenditure of its utmost effort, to win its rightful foundations of existence, independent of its environment. . . . Not long ago many of us felt that learning (Wissenschaft) was too aloof from the great decisions of our time to co-operate in the great struggle of the German people. But the course of German history has itself brought this idyllic attitude to an end and with it has ended also certain idyllic forms of scientific work. The Nazi Revolution summoned science to the decisive battle."

Herr Rust then turned to the question of the freedom of science and of learning: "Complete freedom of opinion and judgment," he said, "are not marks of a truly free science, but rather of an es. trangement of the spirit from the eternal forces of Nature and of history. . . . Freedom is assured to science neither by its abstractness nor by its independence of current events. . . . It is rather the hopes of the German people and of the Nazi State in the share of science in the Four Year Plan . . . that give proof of the recognition of the freedom of science.

"If the Nazi State calls on German science to cooperate in the Four Year Plan, it is not because it anticipates the findings of science but because the first task of science will be to give us those materials which Nature has denied us. Such a task can only be accomplished by free science. For science is unfree if her findings be dictated by an unscientific force, but she is free if she sovereignly masters those problems which are posed to her by life. . . . With the foundation of this Council no new principle of scientific behaviour is introduced. . . What is new is the determinate and planned co-operation of technology and of science for the self-sufficiency of the German economy."

The president of the Council, General Becker, spoke of the reduction in number of the independent centres of research in Germany with the object of concentrating research on more immediate ends. He then turned to consider the way in which the new Council would further the unification of research on methods of preparing raw materials and on their employment. Here, he pointed out, a special position was occupied by the Kaiser Wilhelm Gesellschaft zur Förderung der Wissenschaften.

"The status of the Kaiser Wilhelm Gesellschaft," he said, "will not be disturbed by the new process of 
organization. Those in authority regard its maintenance as necessary not only because of the respect which it enjoys abroad but also for the purpose of linking research with industry. The necessary cooperation between the State Council for Research and the Kaiser Wilhelm Gesellschaft is for the present guaranteed; first, by the common supervision of both bodies by the Reichsminster (Herr Rust), secondly, by the appointment of the directors of two of the Kaiser Wilhelm Institutes as heads of Departments of the State Council for Research, and finally by my own membership of the Senate of the Kaiser Wilhelm Gesellschaft. Later it will be essential, by suitable measures, to bring the directors of all the Kaiser Wilhelm Institutes into closer relations with the State Council for Research. The Ministerial decree founding the Council," he added, "designates the furtherance of the Four Year Plan as one of the Council's most important tasks."

The careers of the heads of all departments of the new Council are set forth in the publication, those of the president and vice-president being stated as follows :

"Artillery-General Professor Karl Becker. Born 1879. From 1900 Artillery Officer. 1906-14 in the Military Technical Academy and active as referee in ballistics. $1914-16$ on active service in charge of a $42 \mathrm{~cm}$. battery and then until the end of the War ballistic expert of the Artillery Investigation Commission. From 1919, ballistic expert in the Armaments Office and from 1926 director of its Projectiles and Munitions Department. Since 1932, as director of the Munitions Office Investigation Committee, he has been responsible for the entire technical develop. ments of the Army. In 1933 he became professor ordinarius of military technics, physics and ballistics at the Technische Hochschule in Berlin."

"Staatsminister Dr. Otto Wacker. Vice-president of the State Council of Research. Head of the office for Learning (Wissenschaft) in the Ministry of Learn. ing, Training and National Education. Born 1899. During the War he was a 'front fighter' on the western front. After the War he studied architecture at the Technische Hochschule at Karlsruhe. Since 1925 he has studied German literature and history at Freiburg, where he took his doctorate. During the revolutionary period he became a district leader (Kreisleiter). He also wrote for the Baden journal Der Führer. In 1933 he became Kultus and Education Minister of Baden. With the nationalization of justice in 1934, he became Minister of Justice for Baden. $\mathrm{He}$ is also an SS Commander (Oberführer)."

The fourteen departments already organized by the Council are as follows : (1) Physics, including mathematics, astronomy and meteorology ; (2) Chemistry and physical chemistry, under the direction of General Becker himself; (3) Power materials ; (4) Organic industrial materials, artificial products, rubber, textiles, fats, cellulose; (5) Non-ferrous metals; (6) Geology, including mineralogy and geophysics; (7) Agriculture and general biology, ineluding zoology and botany ; (8) Forestry and timber research ; (9) Military science and technics, under General Becker himself; (10) Electro-technics; (11) Mining and smelting ; (12) Iron and steel ; (13) Medicine, including race research and race biology; (14) Military medicine.

\section{Medical Research in Canada}

\section{Medical Research Committee}

\begin{abstract}
A COMMITTEE to study the organization of medical research in Canada has been appointed by the National Research Council. This action was taken on the recommendation of a nationwide conference on medical research held in Ottawa recently, which was attended by representatives of all the medical schools, organizations and institutions concerned in medical research, including the provincial departments of health, the Department of Pensions and National Health, and the National Research Council. Sir Frederick Banting has been appointed chairman of the new committee. The president of the National Research Council, the deputy minister of the Department of Pensions and National Health, the president of the Canadian Medical Association, and the president of the Royal College of Physicians and Surgeons of Canada are to be ex-officio members of the committee. To complete the personnel of the committee invitations have been extended to twelve distinguished members of the medical profession who have a comprehensive knowledge of Canada's requirements in medical research.
\end{abstract}

It has been suggested by many members of the medical profession that the formation of this committee on medical research under the National Research Council might well be a first step towards the formation of a medical research council for Canada similar to that which exists in Great Britain. Commenting on this suggestion, Major-General McNaughton, president of the National Research Council, speaking at the conference, said that "the National Research Council is approaching the problem of organization of medical research at present as a preliminary measure only. When a purely medical research council becomes necessary, there will be no opposition whatever from the National Research Council. In fact, the National Research Council will give every assistance possible in order to help a movement that in the opinion of the Council is very important for the welfare of the people of Canada."

The immediate purpose of the committee is defined in the terms of reference, which are: $(a)$ to receive suggestions for requirements in respect of medical research and in matters related thereto; $(b)$ to consider by whom the investigations required can best be carried out and to make proposals accordingly ; (c) to correlate the information when secured and to make it available to those concerned; $(d)$ to do such other things as the committee may deem advisable to promote medical research in Canada.

The conference agreed that the scope of the new committee's activities should not be limited to particular subjects, but that it should be empowered 